\title{
NASA-TM=-103698
}

NASA Technical Memorandum 103698

\section{Space Reactor/Stirling Cycle Systems for High Power \\ Lunar Application}

Paul C. Schmitz

Sverdrup Technology, Inc.

Lewis Research Center Group

Brook Park, Ohio

and

Lee S. Mason

National Aeronautics and Space Administration

Lewis Research Center

Cleveland, Ohio

Prepared for the

8th Symposium on Space Nuclear Power Systems

cosponsored by the University of New Mexico, National Aeronautics and

Space Administration, Strategic Defense Initiative Organization,

U.S. Department of Energy, and U.S. Air Force

Albuquerque, New Mexico, January 6-10, 1991 


\section{DISCLAIMER}

This report was prepared as an account of work sponsored by an agency of the United States Government. Neither the United States Government nor any agency Thereof, nor any of their employees, makes any warranty, express or implied, or assumes any legal liability or responsibility for the accuracy, completeness, or usefulness of any information, apparatus, product, or process disclosed, or represents that its use would not infringe privately owned rights. Reference herein to any specific commercial product, process, or service by trade name, trademark, manufacturer, or otherwise does not necessarily constitute or imply its endorsement, recommendation, or favoring by the United States Government or any agency thereof. The views and opinions of authors expressed herein do not necessarily state or reflect those of the United States Government or any agency thereof. 


\section{DISCLAIMER}

Portions of this document may be illegible in electronic image products. Images are produced from the best available original document. 


\title{
SPACE REACTOR/STIRLING CYCLE SYSTEMS FOR HIGH POWER LUNAR APPLICATIONS
}

\author{
Paul C. Schmitz \\ Sverdrup Technology, Inc. \\ Lewis Research Center Group \\ Brook Park, Ohio \\ Lee S. Mason \\ National Aeronautics and Space Administration \\ Lewis Research Center \\ Cleveland, Ohio
}

\section{INTRODUCTION}

NASA's Space Exploration Initiative (SEI) has proposed the use of high power nuclear power systems on the lunar surface as a necessary alternative to solar power. Because of the long lunar night ( 14 earth days) solar powered systems with the requisite energy storage in the form of regenerative fuel cells or batteries becomes prohibitively heavy at high power levels $(\sim 100 \mathrm{kWe})$. At these high power levels nuclear power systems become an enabling technology for variety of missions. One way of producing power on the lunar surface is with an SP-100 class reactor coupled with Stirling power converters. In this study, analysis and characterization of the SP-100 class reactor coupled with Free Piston Stirling Power Conversion (FPSPC) system will be performed. Comparison of results with previous studies of other systems, particularly Brayton and Thermionic ${ }^{1}$, are made.

\section{ANALYSIS}

Analysis and characterization of a nuclear reactor power system to meet the requirements of Case $5 \mathrm{~A}$ (Case 5 with insitu resource utilization) of NASA's 90 day study is performed. 2 Table 1 shows the requirements for this lunar base. Fig. 1 shows the plant configuration considered in this study. It makes use of the lunar soil to provide the majority of the radiation shield by placing the reactor in an excavation. This also allows maintenance to be performed on all systems outside the reactor cavity. To provide commonality with the other systems previously studied the system was designed to produce 1000 Volts DC output 250 meters from the source. Redundancy for the system is provided by having six converters operational at any one time with two additional converters as backup.

\section{TABLE 1. \\ Lunar Base Power System Requirements}
Power Output to Switch Gear Life of Power System
Equivalent Sink Temperature
Assumed

\author{
$550 \mathrm{kWe}$ \\ 10 Years \\ $250 \mathrm{~K}$ ( Vertical Radiator with \\ Reflective Blanket)
}

Characterization of the components which make up the system is performed by making mass and efficiency estimates for each of them as a function of the electrical or thermal power required. With electrical power fixed a temperature ratio and Stirling converter specific mass is chosen. From this the efficiency of the Stirling converter is found and the amount of heat input and heat rejection can be calculated. The various components are then sized to meet these requirements. The minimum mass point for a given power level is found by varying these system parameters. The maximum temperature 
of the system is set by material considerations either in the power conversion device or in the reactor. The various components used to make up the system are described below.

\section{Reactor}

The reactor is modeled by RSMASS. ${ }^{3}$ RSMASS is a modeling tool used to predict the mass of a reactor and shield. Although the majority of shielding is provided by the lunar soil, shielding is required for the instrumentation and control systems in the excavation. The instruments needing the most shielding are the multiplexers and these set the dose requirements. Dose fluences allowed at the multiplexers (located 1.5 meters from the core) are $1.6 \times 10^{15} \mathrm{nvt}$ and $1.2 \times 10^{8} \mathrm{rad}$, which is consistent with the SP-100 design. The maximum bulk fluid temperature out of the reactor is $1375 \mathrm{~K}$.

\section{Stirling Power Conversion Units (PCU's)}

The Stirling PCU's are modeled using Mechanical Technology Inc. (MTI) scaling study results. ${ }^{4}$ The scaling study provides efficiency as a function of temperature ratio, power output per engine, and the specific mass of the converter. The model is based on MTI's dual opposed Stirling Converter. The two heater head temperatures which are considered in this analysis are $1050 \mathrm{~K}$ and $1300 \mathrm{~K}$. This study assumes the $1050 \mathrm{~K}$ and the $1300 \mathrm{~K}$ power converters have similar mass and efficiency tradeoffs.

\section{Intermediate Liquid Metal Loop}

It is desired to prevent activated coolant from leaving the reactor excavation and to provide power conversion redundancy. One method of achieving this is by placing an intermediate heat exchanger, pumps, piping, accumulators,coolant, decay heat pump, and insulation between the reactor and the Stirling converters. This effectively decouples the primary loop from the Stirling converters and prevents the activated coolant leaving the hole while providing independent loops to the Stirling converters. The lithium to $\mathrm{NaK}$ heat exchangers plus the requisite pumps, piping, etc. are modeled as a function of thermal power.

\section{Radiator}

Two different types of heat rejection subsystems are used for the two systems studied. The $1050 \mathrm{~K}$ system uses a $\mathrm{NaK}$ pumped loop coupled to a water heat pipe radiator while the $1300 \mathrm{~K}$ system uses a liquid metal pumped loop radiator. Because of the high rejection temperature of the $1300 \mathrm{~K}$ system, water heat pipes were not possible. Mercury heat pipes are a candidate but were not chosen because of vehicle contamination concerns. Because the Stirling converter operates at nearly constant rejection temperature the temperature drop from the inlet to the outlet of the radiator is small. Both these radiator concepts are under development at NASA Lewis Research Center under the Civil Space Technology Initiative (CSTI) High Capacity Power Project and have radiator specific mass goals of $5.0 \mathrm{~kg} / \mathrm{m}^{2}$. The study assumes that these radiator goals can be met. A highly reflective blanket is placed underneath the radiators to reduce the effective lunar sink temperature from $325 \mathrm{~K}$ to $250 \mathrm{~K}$. The design and redundancy of the Stirling Power converters and radiators is identical to that of Mason and Bloomfield providing an effective sink of $250 \mathrm{~K}$ in the spoked wheel configuration. ${ }^{5}$

\section{Linear Alternator Radiator}

Because of the temperature constraints on the linear alternator imposed by the samarium-cobalt magnets, a cooling loop for the alternator is required when the temperature of the alternator exceeds $525 \mathrm{~K}$. Because of the small size of the radiators, pumps and ducting are a larger percent of the system mass and require a heavier, $7.5 \mathrm{~kg} / \mathrm{m}^{2}$ specific mass radiator. This is provided by a NaK pumped loop system coupled with water heat pipes. The thermal power required to be rejected is 
based on the temperature ratio of the Stirling converter and the temperature difference between the cooler heat exchanger and the linear alternator.

\section{Power Conditioning}

FPSPC's have the potential of producing a variety of output voltages. Increases in output voltage are accomplished by increasing the wire turns in the alternator. As the voltage increases, the size of the wire can decrease because of the associated decrease in current. Insulation thickness stays relatively constant because the voltage between turns is maintained at approximately 5 volts. Therefore, as alternator voltage increases, a negligible increase in converter mass results. An output voltage of 1000 Vrms was chosen.

The mass of the capacitors to correct the power factor to unity is included in the mass of the Stirling converters.

To meet the requirement of 1000 volt DC output, power conditioning in the form of a rectifier and filter is needed. Rockwell developed models to estimate the mass of these components, and they are used in this study. ${ }^{6}$ Radiators are required to reject the heat produced by inefficiencies in the PMAD systems, and these are also modeled. Fifteen meter aluminum cables are used to couple the Stirling PCU's to the rectifier. A single 250 meter cable will take the conditioned 1000 Volt DC power to the switch gear which links this to the lunar electrical power grid.

\section{RESULTS}

Fig. 2. shows the surface representing total system mass that is generated by varying both temperature ratio and Stirling converter specific mass for a $1050 \mathrm{~K}, 550 \mathrm{kWe}$ Stirling lunar base application. The tradeoff between high efficiency heavy Stirling converters and light weight, less efficient converters is seen. It should be noted that some points on the surface are extrapolated beyond the range of the scaling study results. None of the systems considered optimized at these extrapolated points. Table 2 shows the mass breakdown at $550 \mathrm{kWe}$ for $1050 \cdot \mathrm{K}$ and $1300 \mathrm{~K}$ heater head temperatures. The $1050 \mathrm{~K}$ Stirling converter optimizes at a temperature ratio of 2.0 and a Stirling converter specific mass of $4.8 \mathrm{~kg} / \mathrm{kWe}$. At a temperature ratio of 2.0 , (cooler heat exchanger temperature of $525 \mathrm{~K}$ ) the linear alternator radiator is not required. The $1300 \mathrm{~K}$ system has a minimum mass at temperature ratio of 2.3 and a converter specific mass of $4.0 \mathrm{~kg} / \mathrm{kWe}$. Compared to its lower temperature counterpart it offers a reduction in mass of $20 \%$ and a reduction in radiator area of $45 \%$. At converter cold-end temperatures above $525 \mathrm{~K}$ the alternators must be cooled. The minimum mass $1300 \mathrm{~K}$ system requires a linear alternator radiator of $34.21 \mathrm{~m}^{2}$ which weighs $342.08 \mathrm{~kg}$.

Besides the $550 \mathrm{kWe}$ design point, it was also desired to look at how a lunar base power plant would scale with various electrical power levels. System studies were made at 100 and $1000 \mathrm{kWe}$ levels. This represents the current range of power levels envisioned for this class of Stirling converters. Fig. 3 shows system mass and radiator area as a function of power level. At each power level both Stirling converter specific mass and temperature ratio are varied to arrive at a minimum overall system mass. As the electrical power level increases, the mass of the radiator becomes a more significant part of the system mass. This makes the advantages of high temperature (i.e. $1300 \mathrm{~K}$ ) more important.

Several other types of nuclear reactor power systems could be utilized to produce the required electrical power. Two of the more promising systems, Brayton and incore Thermionics have been modeled at $550 \mathrm{kWe}$ to the same requirements.

Two Brayton systems are considered, the first operates at a turbine inlet temperatures (TIT) of 1140 $\mathrm{K}$ (corresponding to the mini BRU program ${ }^{7}$ ) while the second utilizes high temperature refractory metal components and operates at a TIT of $1300 \mathrm{~K}$. The Brayton system analysis was done for a recuperated Brayton cycle with a SP-100 reactor and includes a liquid metal to gas heat exchanger to transfer heat to the working fluid. This heat exchanger is in the reactor cavity (as is the case for the Stirling and thermionic systems) and does not permit activated coolant to leave the excavation and also provides redundancy for the power converters. The mass algorithms for the Brayton cycle are based on $\mathrm{CCEP}^{8}$ while the reactor and shield are sized using RSMASS. Temperature ratio, pressure ratio, 
and recuperator effectiveness are varied to find the minimum system mass. The same redundancy is used in the Brayton system as in the Stirling systems.

The baseline thermionic system assumed \pm 7.5 Volt reactor output, a conservative interelectrode gap and a $1800 \mathrm{~K}$ emitter temperature. The advanced thermionics assumed a \pm 50 Volt output, a reduction in interelectrode gap and a $20000 \mathrm{~K}$ emitter temperature. The largest single impact on the thermionic system mass was the assumption of higher output voltages from the reactor core. These advanced goals with higher output voltage is not part of the TFE program and several issues must still be resolved before this higher output voltage is possible. The requirement that no activated coolant leaves the excavation is applied to all the systems considered.

Fig. 4 shows a comparison of the Stirling system to the other systems based on mass. Of the near term technology systems (i.e the $1050 \mathrm{~K}$ Stirling, $1140 \mathrm{~K}$ Brayton, and Baseline thermionics) the Stirling system provides minimum mass. All three of the advanced technology systems provide, within the accuracy of this study, the same mass. Fig. 5 shows a radiator area comparison with the baseline and advanced thermionic systems providing the smallest radiator areas. The reason the thermionic systems have small radiators is that their rejection temperature is around $900 \mathrm{~K}$. Although the advanced thermionic system has the smallest radiator, the $1300 \mathrm{~K}$ Stirling system is a close second. The high temperature Brayton and the low temperature Stirling have similar radiator areas.

A $10 \%$ reduction in mass can occur for the Stirling systems if the intermediate liquid metal loop is removed. Alternate low mass approaches for the intermediate loop are currently being studied; these would maintain the goal of isolating the reactor loop and allowing converter maintenance. Two other approaches allow the removal of this loop. The first is to allow activated coolant to pass over the heater heads of the Stirling converters and only permit maintenance after the coolant activation has decreased. The second is to place the Stirling converters in the reactor excavation. This method precludes maintenance. These options need to be examined further.

\section{CONCLUSION}

Stirling converters at both the $1050 \mathrm{~K}$ and $1300 \mathrm{~K}$ heater head temperatures offer low mass, high efficiency systems for lunar base applications. Both high and low temperature Stirling systems have the benefits of fitting into the SP-100 reactor program while providing reductions in radiator mass and size when compared to Brayton power conversion systems. Low temperature Stirling systems offer the lowest mass of all the low temperature systems considered. Of the high temperature Brayton, Stirling, and thermionic systems considered, all are comparable in mass. A significant reduction in radiator area over the Brayton systems can be achieved if the thermionic or high temperature Stirling systems are used. One draw back of these thermionic reactor systems are that if the advanced technology goals are not met, this reactor/power conversion system can not be coupled with other power conversion schemes.

At $100 \mathrm{kWe}$ a reduction in specific mass from $35.2 \mathrm{~kg} / \mathrm{kWe}$ to $31.2 \mathrm{~kg} / \mathrm{KWe}$ (a $10 \%$ reduction in system mass) occurs when going from $1050 \mathrm{~K}$ to $1300 \mathrm{~K}$ heater head temperatures. At $1000 \mathrm{kWe}$ the reduction in specific mass is from $19.1 \mathrm{~kg} / \mathrm{kWe}$ to $15.2 \mathrm{~kg} / \mathrm{kWe}$, or a $20 \%$ reduction in system mass. At $550 \mathrm{kWe}$ the reduction in specific mass is from $20.5 \mathrm{~kg} / \mathrm{kWe}$ to $16.8 \mathrm{~kg} / \mathrm{kWe}$, or a $18 \%$ reduction in system mass. For the $550 \mathrm{kWe}$ system the total radiator area is reduced from $628.46 \mathrm{~m}^{2}$ to 356.45 $\mathrm{m}^{2}$. This decrease in radiator area is the primary reason for the reduction in system mass. This clearly shows the increasing importance of high temperature converters as the electrical power output increases

1 L. Mason ,P. C. Schmitz, and D. Gallup 'Lunar In-Core Thermionic Nuclear Reactor Power System Conceptual Design', Eighth Space Nuclear Power Symposium, January, 1991.

2 D. A. Petri, R.L. Cataldo, J.M. Bozek, "Power System Requirements and Definition for Lunar and Mars Outposts", Proceedings of the 25th Intersociety Energy Conversion Engineering Conference, August 1990. 
3 A. C. Marshall, "RSMASS: A Preliminary Reactor/Shield Mass Model for SDI Applications", SAND86-1020, August 1986.

4 D. Jones, "Space Power Free Piston Stirling Engine Scaling Study", NASA CR182218, October 1989

5 L. Mason, H. Bloomfield, and D. Hainley,"SP-100 Power System Conceptual Design for Lunar Base Applications", Sixth Space Nuclear Power Symposium, January 1989

6 K. Metcalf, "Lunar/Mars Mission Energy/Power System Assessment Studies", NAS3-25808, Rockwell International, August, 1990.

7 R. E. English, "Power Generation from Nuclear Reactors in Aerospace Applications", NASA Technical Memorandum TM 83342, November 1982.

8 J. Klann, "Analysis and Selection of Design Conditions for a Radioisotope Brayton-Cycle Space Powerplant”, NASA Technical Note TN D-4600, June 1968.

\title{
DISCLAIMER
}

\begin{abstract}
This report was prepared as an account of work sponsored by an agency of the United States Government. Neither the United States Government nor any agency thereof, nor any of their employees, makes any warranty, express or implied, or assumes any legal liability or responsibility for the accuracy, completeness, or usefulness of any information, apparatus, product, or process disclosed, or represents that its use would not infringe privately owned rights. Reference herein to any specific commercial product, process, or service by trade name, trademark, manufacturer, or otherwise does not necessarily constitute or imply its endorsement, recommendation, or favoring by the United States Government or any agency thereof. The views and opinions of authors expressed herein do not necessarily state or reflect those of the United States Government or any agency thereof.
\end{abstract}




\section{TABLE 2. \\ 550 kWe Stirling Power Converters}

Heater Head Temp

Temp Ratio

Cycle Efficiency

Radiator Area

Linear Alternator Radiator

\author{
Low Temp \\ $1050 \mathrm{~K}$ \\ 2 \\ $28.98 \%$ \\ 628.32 \\ $\mathrm{m}^{\wedge} 2$ \\ $0.0 \mathrm{~m}^{\wedge} 2$
}

High Temp $1300 \mathrm{~K}$

2.3

$33.50 \%$

356.45

$\mathrm{m}^{\wedge} 2$

$34.2 \mathrm{~m}^{\wedge} 2$

\section{Mass Breakdown of System (kg)}

\author{
Reactor \\ Shield \\ Intermediate Liquid Metal Loop \\ Liquid Metal Pumps \\ Primary Piping, Accum, etc. \\ Stirling PCU/Alternator \\ Main Radiator \\ Alternator Radiator \\ Structure \\ Reactor Bulkhead \\ Upper Scatter Shield \\ Reactor Support Stand \\ Excavation Sleeve \\ Excavation Cooling System \\ Transmission Line $(250 \mathrm{~m})$ \\ Power Conditioning \\ Rectifier \\ Filter \\ Enclosure \\ Radiator \\ Misc.
}

Total Base Mass

(kg)
1047.6

386.5

797.8

692.34

748.35

3610.26

3142.29

0

1146.78

783

112.1

52.3

56.5

49.5

479.1

188.08

150.87

217.61

171.22

101.29

13933.5
1042.8

374.22

712.32

645.03

667.9

3008.5

1782.2

342.08

943.27

783

112.1

52.3

56.5

49.5

479.1

188.08

150.87

217.61

171.22

101.29 


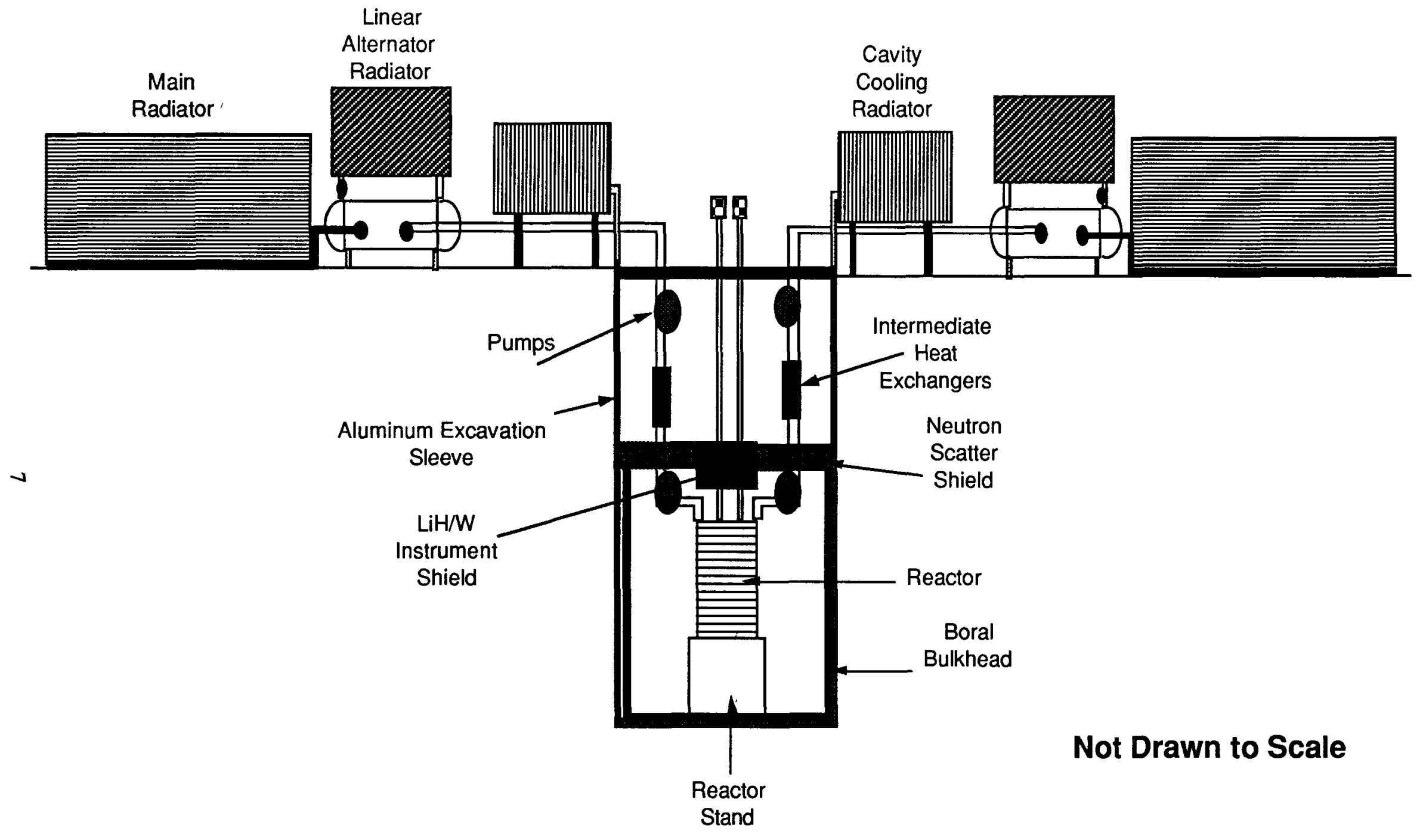

FIGURE 1. Lunar Base Cutaway 


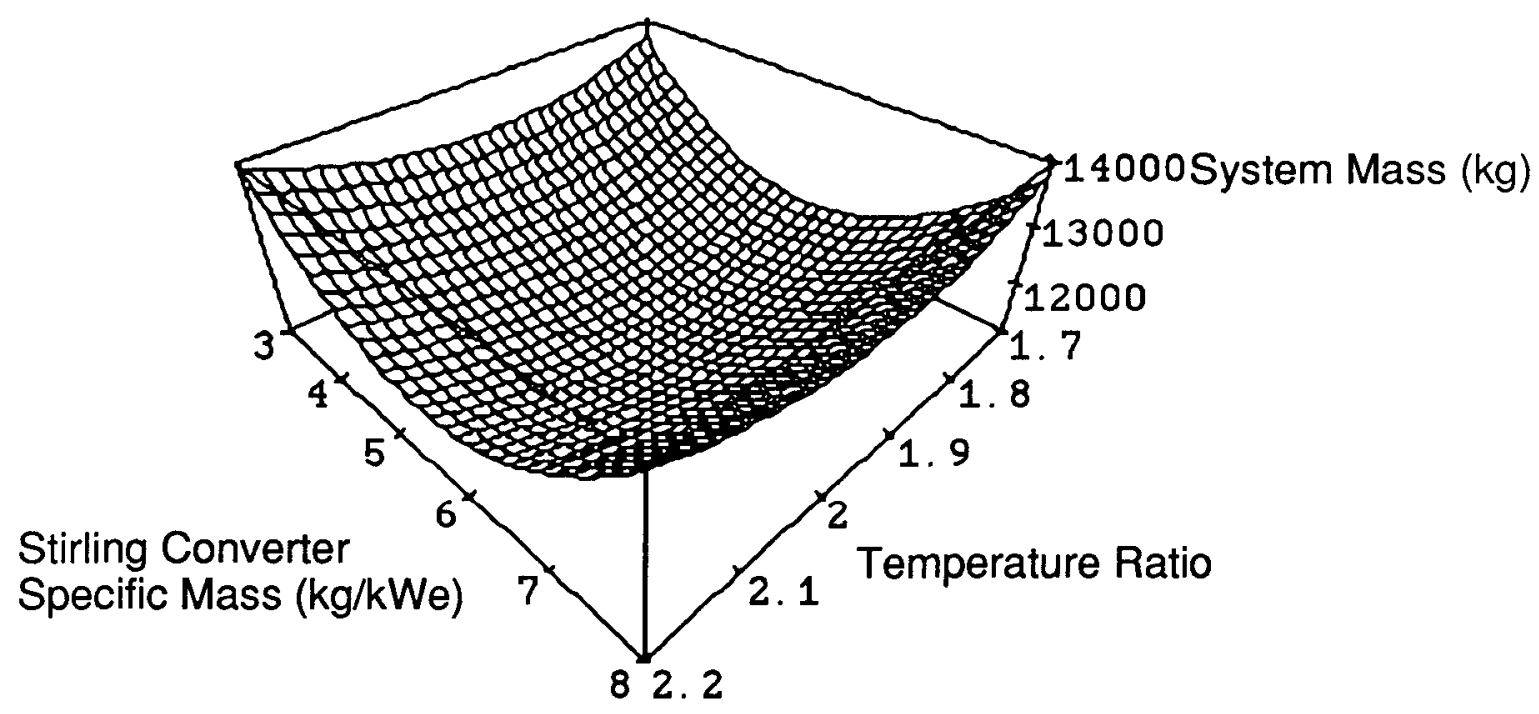

FIGURE 2. System Optimization Surface

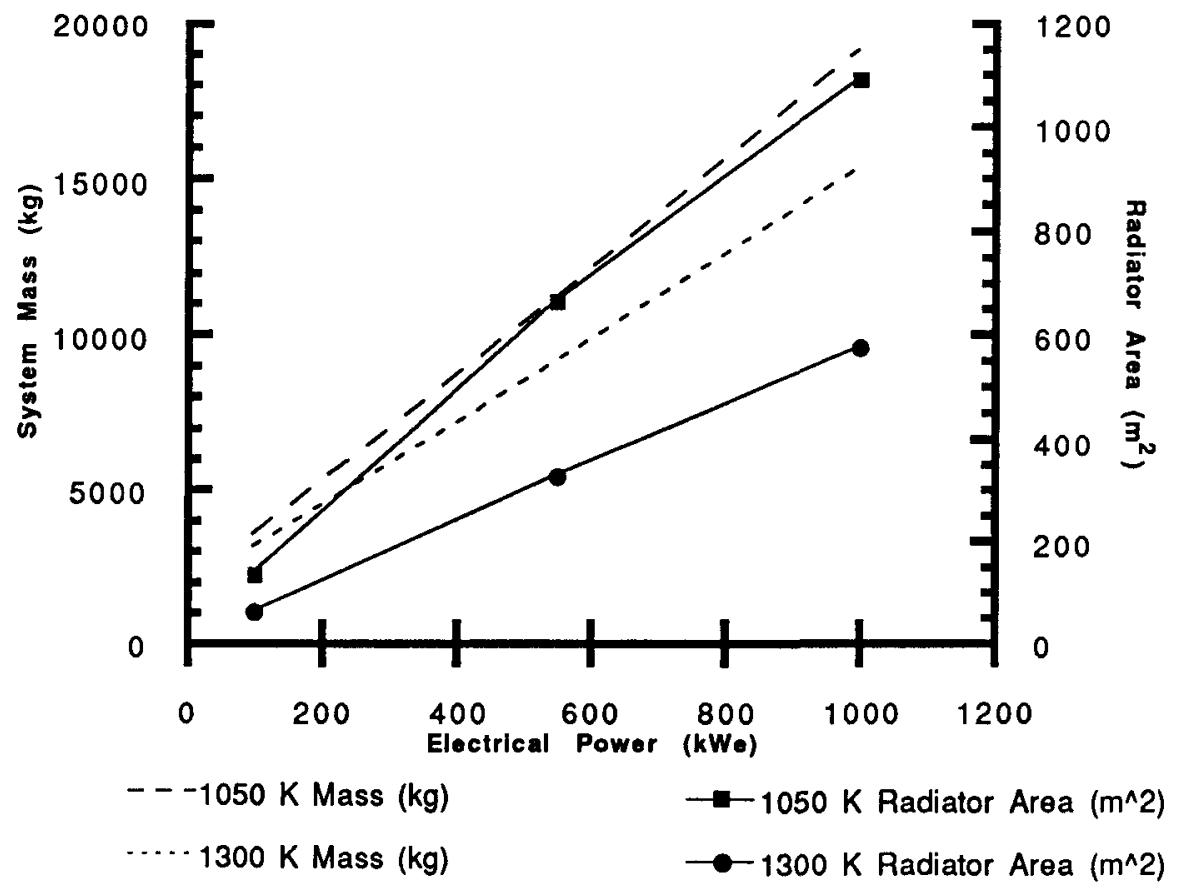

FIGURE 3. Mass and Radiator Area as a Function of Electrical Power Level 


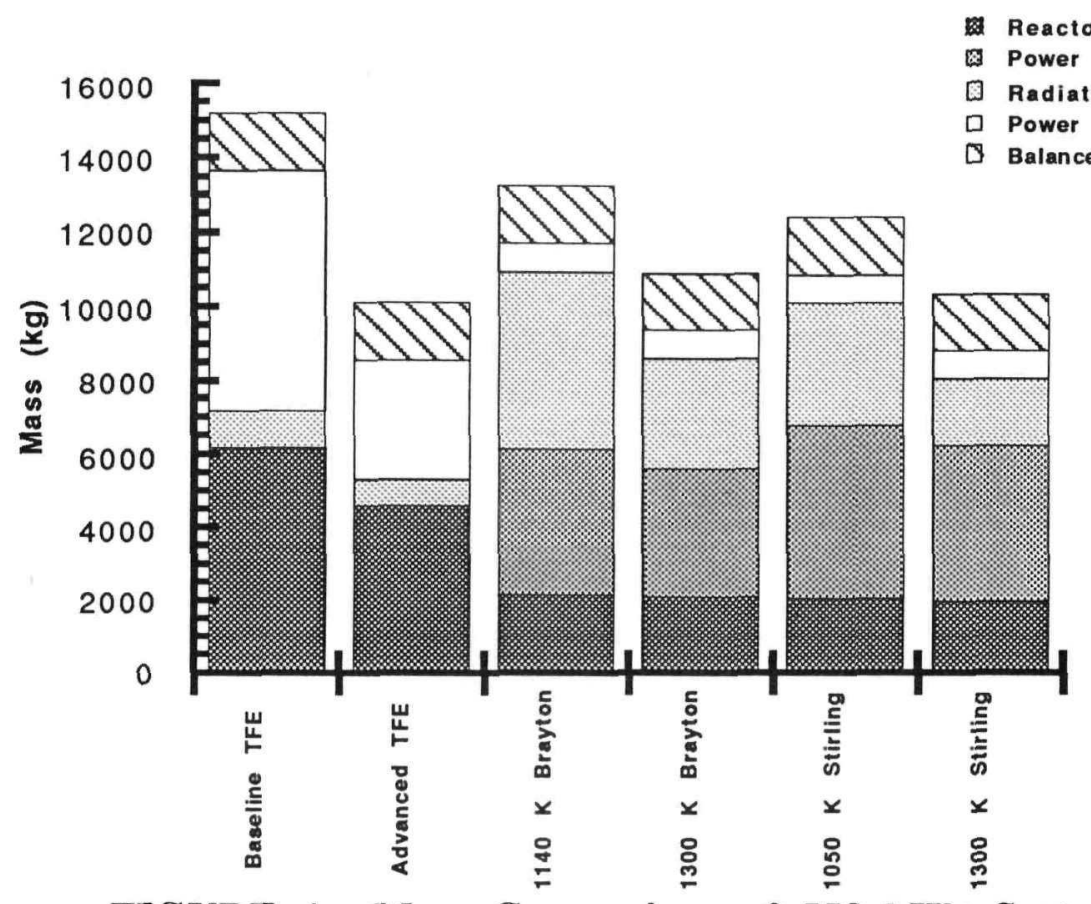

FIGURE 4. Mass Comparison of $550 \mathrm{kWe}$ Systems

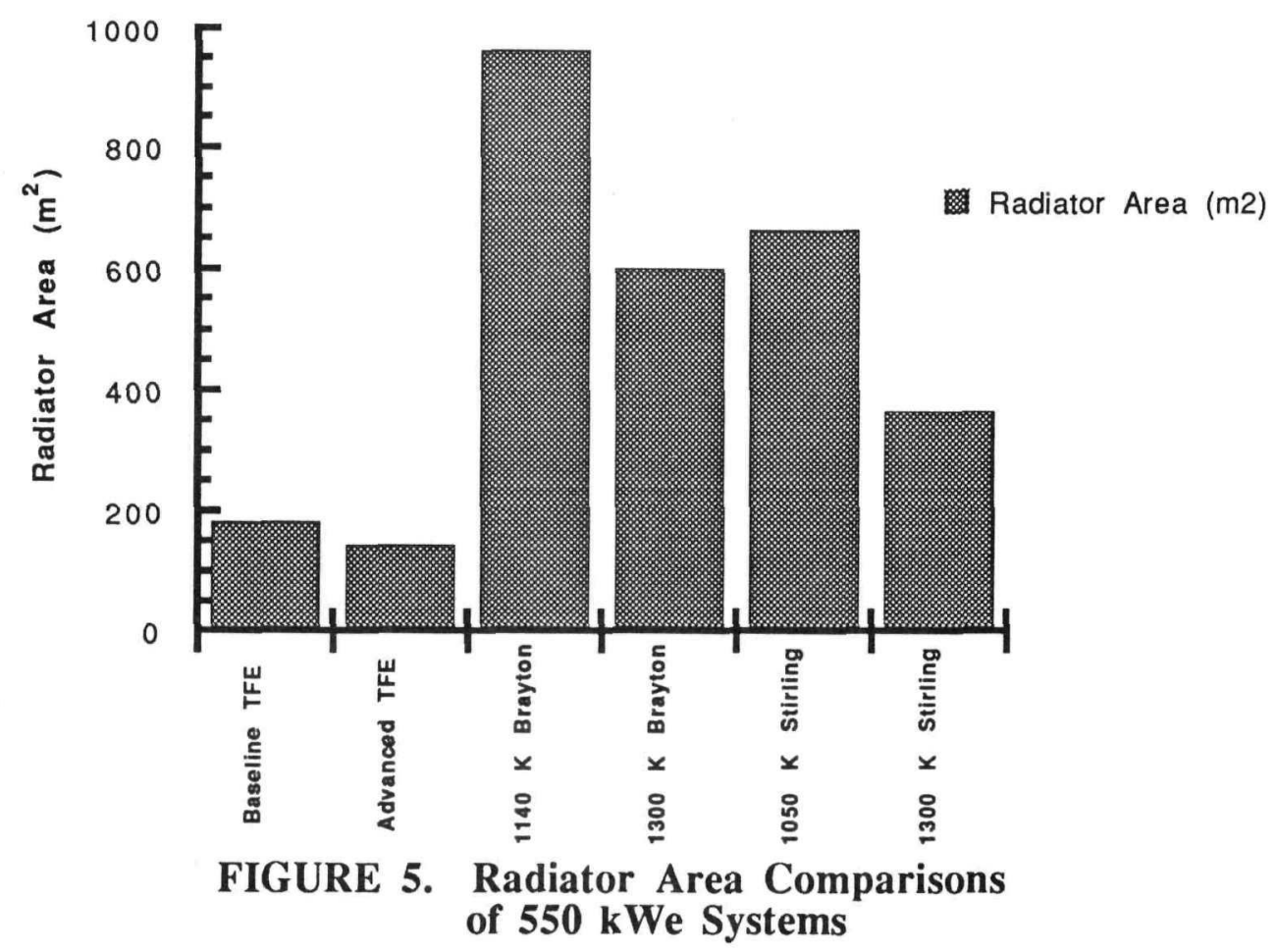




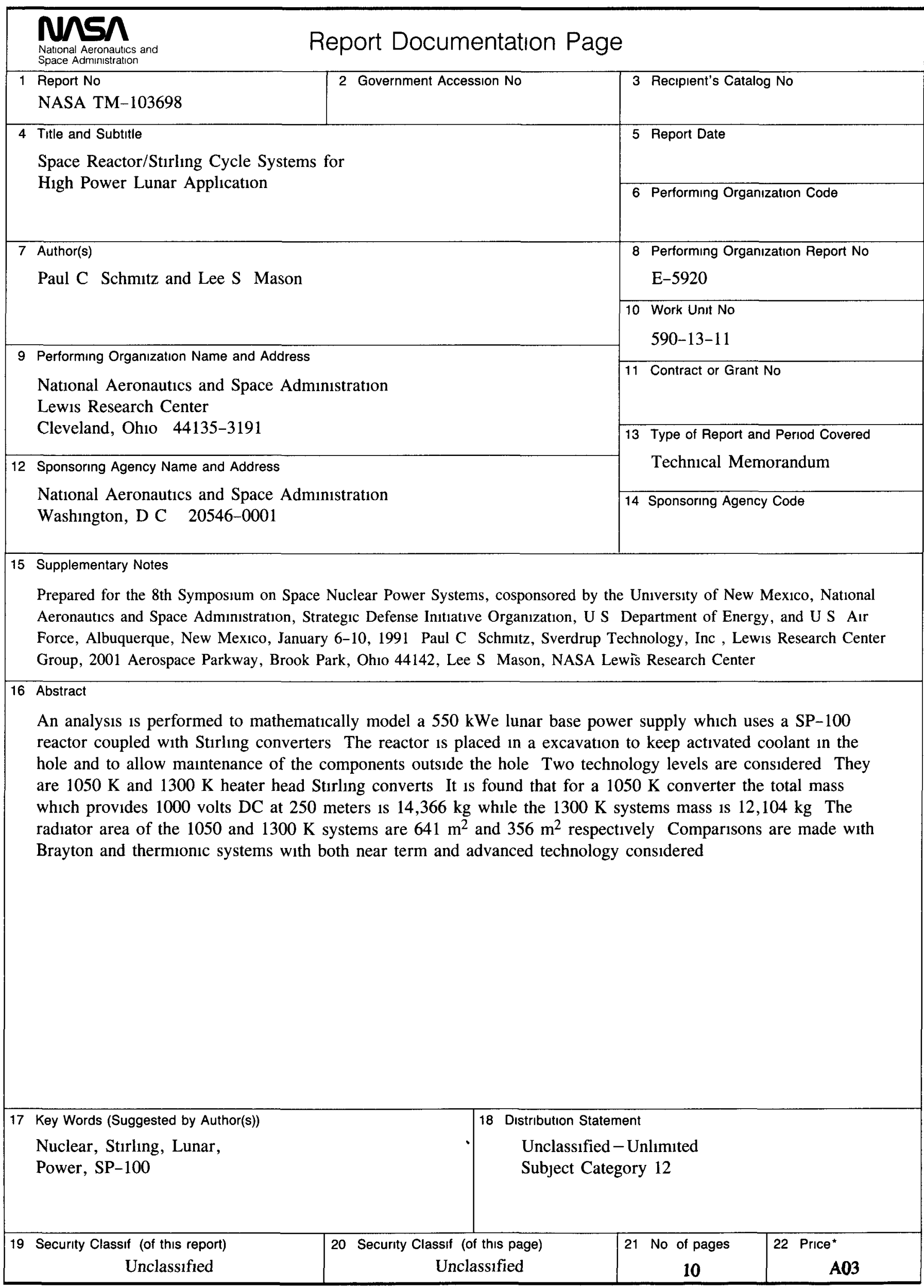


National Aeronautics and Space Administration

Lewis Research Center

Cleveland, Ohio 44135

Orficial Business

Penalty for Private Use $\$ 300$

ADDRESS CORRECTION REQUESTED

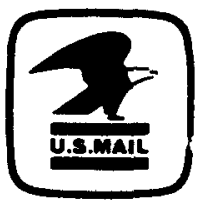

Postage and Fees Pard National Aeronautics and Space Administration NASA 451 